\title{
PERTUMBUHAN EKONOMI DAN KEMISKINAN
}

\author{
Zulkarnain Nasution \\ Dosen Tetap Sekolah Tinggi Ilmu Ekonomi (STIE) Labuhanbatu
}

\begin{abstract}
ABSTRAK
Tujuan dari penelitian ini adalah untuk mengetahui kondisi pertumbuhan ekonomi di Negaranegara berkembang, permasalahan-permasalahan pertumbuhan ekonomi kemiskinan di negara berkembang, faktor-faktor yang menyebabkan kemiskinan, konsep-konsep tentang kemiskinan serta kebijakan yang diambil oleh Negarauntuk mengatasi permasalahan tersebut. Metode penelitian yang digunakan adalah penelitian deskriptif. Hasil penelitian menunjukan bahwa untuk mengatasi masalah pertumbuhan, kemiskinan dan distribusi pendapat kini dikaitkan dengan perbaikan sistem dan struktur, tidak semata-mata bertumpu pada aksi sesaat berupa crash program. Selain itu juga membuat kebijakan strategis dengan cara perluasan dan pemerataan pendidikan, peningkatan layanan kesehatan, pembangunan perumahan, penciptaan lapangan kerja, pembangunan infrastruktur untuk memperlancar transaksi ekonomi dan perdagangan, serta pembangunan daerah untuk mengurangi disparitas ekonomi antar wilayah.
\end{abstract}

\section{Pendahuluan}

Masalah besar yang dihadapi negara sedang berkembang adalah Distribusi pendapatan dan tingkat kemiskinan. Tidak meratanya distribusi pendapatan memicu terjadinya ketimpangan pendapatan yang merupakan awal dari munculnya masalah kemiskinan. Membiarkan kedua masalah tersebut berlarut-larut akan semakin memperparah keadaan, dan tidak jarang dapat menimbulkan konsekuensi negatif terhadap kondisi sosial dan politik. Dalam distribusi pendapatan baik antar kelompok berpendapatan, antar daerah perkotaan dan daerah pedesaan, atau antar kawasan dan propinsi dan kemiskinan merupakan dua masalah yang masih mewarnai perekonomian Indonesia. Pada awal pemerintahan orde baru,

Masalah kesenjangan pendapatan dan kemiskinan tidak hanya dihadapi oleh negara sedang berkembang, namun negara maju sekalipun tidak terlepas dari permasalahan ini. Perbedaannya terletak pada besar kecilnya tingkat kesenjangan dan angka kemiskinan yang terjadi, serta tingkat kesulitan mengatasinya yang dipengaruhi oleh luas wilayah dan jumlah penduduk suatu negara. Semakin besar angka kemiskinan, semakin tinggi pula tingkat kesulitan mengatasinya. Negara maju menunjukkan tingkat kesenjangan pendapatan dan angka kemiskinan yang relative kecil dibanding negara sedang berkembang, Oleh karena itu strategi pembangunan diterapkan oleh pemerintah pada awal periode orde baru hingga akhir tahun 1970-an terpusatkan pada pertumbuhan ekonomi yang tinggi. Untuk mencapai tujuan tersebut maka pusat pembangunan dimulai di Pulau Jawa, khususnya Propinsi Jawa Barat, karena fasilitas seperti infrastruktur lebih tersedia dibandingkan dipropinsi lainnya di Indonesia dan di beberapa propinsi

Berbagai upaya yang telah dan sedang dilakukan oleh dunia internasional, baik berupa bantuan maupun pinjaman pada dasarnya, sector primer dan industri berat, merupakan upaya sistematis untuk memperkecil kesenjangan pendapatan dan tingkat kemiskinan yang terjadi di negara-negara miskin dan sedang berkembang. Beberapa lembaga internasional seperti IMF dan Bank Dunia serta lembaga-lembaga keuangan internasional lainnya berperan dalam hal ini. Kesalahan pengambilan kebijakan dalam pemanfaatan bantuan dan atau pinjaman tersebut, 
justru dapat berdampak buruk bagi struktur sosial dan perekonomian negara bersangkutan. Perbedaan pendapatan timbul karena adanya perbedaan dalam kepemilikan sumber daya dan faktor produksi terutama kepemilikan barang modal. kemudian menyebar sehingga menimbulkan keseimbangan baru. Apabila proses otomatis tersebut masih belum mampu menurunkan tingkat perbedaan pendapatan yang sangat timpang, maka dapat dilakukan melalui sistem perpajakan dan subsidi. Penetapan pajak pendapatan/penghasilan akan mengurangi pendapatan penduduk yang pendapatannya tinggi. Sebaliknya subsidi akan membantu penduduk yang pendapatannya rendah, asalkan tidak salah sasaran dalam pengalokasiannya.

Selama 350 tahun rakyat Indonesia hidup dalam lingkungan kolonialisme penjajah, tidak pernah merasakan keadilan dalam segala bidang. Pada masa penjajahan, ekonomi Indonesia berorientasi untuk menyediakan bahan mentah bagi Belanda. Sektor pertanian selain menyediakan beras sebagai makanan pokok, bangsa Indonesia juga memproduksi rempahrempah yang dapat dijual mahal di pasaran Eropa. Sektor industri tidak berkembang, dikarenakan Belanda tidak mau hasil industri Indonesia bersaing dengan industri yang ada di Belanda.

Sebagai bagian dari dunia internasional, berbagai upaya telah dilakukan oleh Pemerintah Republik Indonesia dalam rangka meningkatkan derajat kehidupan bangsa agar setara dengan negara-negara lainnya di dunia. Kebijakan-kebijakan pembangunan yang diambil dan dilaksanakan "sejatinya" diarahkan pada upaya peningkatan kesejahteraan masyarakat. Berbagai upaya untuk mencapai tujuan tersebut telah banyak dilakukan, termasuk "menjalin hubungan" dengan lembaga-lembaga internasional seperti IMF dan Bank Dunia.

\section{Rumusan Masalah}

1. Bagaimana kondisi pertumbuhan ekonomi di negara - negara berkembang;

2. Bagimana permasalahan-permasalahan pertumbuhan ekonomi;

3. Bagaimana kemiskinan di negara berkembang;

4. Bagaimana faktor-faktor menyebabkan kemiskinan;

5. Bagaimana konsep-konsep tentang kemiskinan;

6. Bagaimana kebijakan yang diambil oleh Negarauntuk mengatasi permasalahan tersebut.

\section{Maksud dan Tujuan}

Tulisan ini untuk mendapatkan gambaran tentang profil kemiskinan di Indonesia, melalui pengkajian berbagai jurnal, artikel, dan penelitian-penelitian terkait. Adapun tujuan dari penulisan ini adalah untuk memperoleh data dan informasi tentang tingkat kemiskinan di Indonesia, serta menentukan langkah-langkah yang dianggap efektif dan efisien dalam upaya penanggulangannya.

\section{Kinerja Perekonomian Indonesia}

Sistem demokrasi yang dianut Indonesia setelah merdeka, adalah Demokrasi Terpimpin, yaitu era dimana "politik menjadi panglima". Presiden Soekarno memfokuskan pembangunan pada upaya peningkatan "persatuan dan kesatuan bangsa". Fokus ini membuat perekonomian di Indonesia tidak tertata dengan rapi (miss management). Sebagai akibatnya perekonomian menjadi semakin hancur. Disebabkan oleh Politik Isolasi Nasional dan menumpuknya defisit APBN dari tahun ke tahun sejak tahun 50-an hingga penggalan pertama tahun 1960-an, maka di tahun 1965-66 terjadi suatu krisis ekonomi nasional yang sangat merisaukan, dan puncaknya Presiden Soekarno harus turun dari pucuk pimpinan Indonesia. 
Keadaan ini telah menumbangkan Orde Lama (Demokrasi Terpimpin) dan terbentuknya Orde Baru.

Di era pemerintahan Presiden Soeharto, Indonesia memfokuskan diri pada pembangunan di "bidang perekonomian". Ini ditandai dengan adanya grand planning pembangunan yaitu Repelita yang dimulai tahun 1969. Pada masa ini pembangunan perekonomian fokus pada upaya meningkatkan investasi luar negeri dan perdagangan. Perkembangan perekonomian Indonesia secara keseluruhan terlihat mengesankan. Secara umum, indikator makroekonomi menunjukkan perkembangan angka dan kondisi mutakhir yang sangat baik. Tidak ada pertanda yang membuat khawatir banyak pihak, terutama bagi pemerintah dan otoritas moneter. Indikator makroekonomi yang dimaksud adalah: pertumbuhan ekonomi, angka inflasi, nilai tukar rupiah, cadangan devisa dan neraca pembayaran. Data BPS menunjukkan bahwa pada tahun 1980-an sampai tahun 1990-an perekonomian Indonesia mengalami kenaikan pesat. Kenaikan ini sebagian besar ditopang dari kontribusi eksploitasi sumber daya alam. Antara tahun 1985 - 1995 GDP Indonesia tumbuh 95\% sementara inflasi dapat ditekan dibawah 10\%. Pertumbuhan ekonom meningkatnya karena konsumsi masyarakat serta kegiatan investasi baik PMDN maupun PMA serta beberapa sektor kegiatan perekonomian lainnya.

Namun di sisi lain, pertumbuhan yang tinggi ini ternyata dibarengi oleh ketimpangan yang sangat besar antara Indonesia Bagian Barat dan Indonesia Bagian Timur, antara perusahaan besar dan perusahaan kecil, antara perkotaan dan perdesaan, antara kelompok etnis yang satu dengan kelompok etnis lainnya. Pembangunan ekonomi dibarengi dengan tumbuh kembangnya $\mathrm{KKN}$, dengan utang pemerintah yang meningkat terus sampai pemerintah tidak mempunyai kekuatan dana untuk melakukan tugas pokok dan fungsinya dalam bidang pendidikan, kesehatan, perumahan, infrastruktur, pertahanan / keamanan dan sebagainya.

Pembangunan ekonomi selama Orde Baru juga tidak mampu menghapus adanya ekonomi dualistik yang membuat tidak adanya hubungan sama sekali antara ekonomi perkotaan dan perdesaan. Masing-masing bekerja sendiri-sendiri dimana ekonomi perdesaan dan rakyat kecil tidak pernah disentuh oleh kebijakan maupun bantuan pemerintah dalam memakmurkan mereka, Ekonomi rakyat/ekonomi tradisional dan ekonomi modern tidak perlu diadakan dikhotomi. "Dual economy" nya Prof. Boeke, adalah suatu kenyataan dan merupakan dua kekuatan ekonomi yang perlu diintegrasikan menjadi sokoguru dari bangunan ekonomi nasional yang modern.

Banyak pengamat menilai bahwa terjadinya dampak krisis yang begitu besar disebabkan karena rapuhnya fundamental perekonomian Indonesia. Sistem ekonomi yang berlaku sekarang ini nyata-nyata telah mendorong perilaku konsumtif masyarakat dan telah menyeret begitu jauh perekonomian nasional untuk tumbuh secara instant. Hanya negaranegara kaya dengan perangkat kelembagaan ekonomi politik yang mantaplah yang bisa mengeliminasikan dampak-dampak negatif dari gelombang pergerakan finansial global ini.

Pemerintahan pasca Soeharto, terutama era Habibie (yang seterusnya dinamakan era reformasi), menjalankan program stabilisasi makroekonomi melalui kebijakan moneter dan fiskal. Program awal difokuskan untuk mengatasi permasalahan yang sangat mendesak pada saat krisis, yaitu: meredam tekanan laju inflasi dan gejolak nilai tukar.

Pemerintah berupaya agar keadaan moneter menjadi stabil dengan pertanda suku bunga yang normal dan nilai tukar rupiah yang realistis, sehingga dapat membantu kebangkitan kembali dunia usaha. Secara bersamaan, pemerintah melakukan berbagai langkah konsolidasi di bidang fiskal melalui peningkatan disiplin anggaran dengan melakukan penghematan atas berbagai pengeluaran pemerintah. Pemerintah juga terpaksa melakukan penjadwalan dan penyesuaian terhadap beberapa proyek pembangunan. Dalam keseluruhan langkah tersebut, upaya restrukturisasi dan penyehatan perbankan menjadi prioritas yang sangat penting. Pengeluaran biaya yang amat besar untuk itu juga dianggap wajar. Perbankan dan „non- 
ekonomi-rakyate yang notabene menjadi penyebab krisis berusaha „diselamatkan ${ }^{\text {ee }}$ dengan menggunakan dana trilyunan rupiah dari sumberdaya negara yang telah sangat terbatas. Pertimbangan utamanya, stabilitas moneter menjadi prasyarat bagi pemulihan ekonomi, dan itu memerlukan stabilitas sistem keuangan. Stabilitas sistem keuangan mensyaratkan pembenahan sektor perbankan, termasuk BI sebagai Bank Sentral.

Kegiatan perekonomian yang diharapkan akan bergairah dengan munculnya rezim pernerintahan baru ternyata tidak terbukti, keadaan perekonomian yang rnemburuk pada saat bersamaan dengan negara-negara lain seperti, Malaysia, Thailand, Korea, Brazil, danlain-lain tidak dapat ditingkatkan, di lain pihak perekonomian dunia, bahkan negara-negara tetangga seperti yang disebutkan di atas telah mampu keluar dari kemelut krisis moneter namun di pihak Indonesia hal tersebut tidak semakin membaik namun para elit dan kelompok partai-partai politik terus saja berpacu dan bergelut dengan perebutan kekuasaan sehingga lupa pada apa yang berhubungan dengan kondisi perekonomian masyarakat yang semakin menimbulkan gejolak sosial, pengangguran semakin bertambah, tingkat kemiskinan semakin besar, keluarnya investor-investor asing, pencucian uang, tingkat korupsi semakin merajalela mulai dari tingkat desa sampai ke pemerintah pusat tidak terkecuali para anggota legislatif yang dikenal dengan money politiknya semakin tidak dapat dibendung sehingga menempatkan Indonesia sebagai negara paling korup nomor 3 (tiga) di dunia dan nomor 1 (satu) di Asia.

Dampak krisis ini telah menernpatkan Indonesia sebagai negara yang mengalami penurunan dalam GNP maupun pertumbuhan ekonomi paling parah di dunia. Krisis moneter telah membuyarkan "buaian" Indonesia dengan GNP dan pertumbuhan ekonomi serta pendapatan per kapita yang rnengagumkan dan cukup "fantatis" untuk ukuran sebuah negara sedang berkembang telah hilang, kondisi perekonomian Indonesia menjadi terpuruk yakni mengalami kemunduran.

Merosotnya kondisi perekonomian ini dalam jangka waktu yang sangat pendek menunjukkan indikasi bahwa sendi-sendi atau fondasi perekonomian Indonesia yang dibangun selama ini tidak memperlihatkan kekuatannya. Terbukti GNP Indonesia atas dasar harga konstan tahun 1993 mengalami penurunan pada tahun 1998 sekitar 374.718,8 milyar dari sekitar 434.095,5 milyar, dan penurunan nilai ini hampir terjadi di semua sektor kegiatan perekonomian.

\section{Kondisi Pertumbuhan Ekonomi di Negara - negara Sedang Berkembang}

Berawal dari permasalahan kegagalan pembayaran kredit perumahan (subprime mortgage default) di Amerika Serikat (AS), krisis kemudian menggelembung merusak sistem perbankan bukan hanya di AS namun meluas hingga ke Eropa lalu ke Asia. Secara beruntun menyebabkan effect domino terhadap solvabilitas dan likuiditas lembaga-lembaga keuangan di negara negara tersebut, yang antara lain menyebabkan kebangkrutan ratusan bank, perusahaan sekuritas, reksadana, dana pensiun dan asuransi. Krisis kemudian merambat ke belahan Asia terutama negara-negara seperti Jepang, Korea, China, Singapura, Hongkong, Malaysia, Thailand termasuk Indonesia yang kebetulan sudah lama memiliki surat-surat beharga perusahaan-perusahaan tersebut.

Dari berbagai kritik para ahli, bahwa problem tersebut dipicu maraknya penggelembungan harga perumahan di AS yang didorong kebijakan-kebijakan Bank Sentral Amerika (the Fed) yang kurang pruden untuk menstabilkan sistem keuangan sejak bertahuntahun. Kondisi ini didorong oleh keinginan untuk memelihara permintaan properti perumahan agar tetap tinggi, maka bank-bank di Amerika Serikat banyak mengucurkan kredit perumahan terutama bagi kalangan berpenghasilan rendah yang tidak memiliki kapasitas keuangan yang memadai (ninja loan yaitu pinjaman terhadap nasabah yang no income, no job, \& no asset). Kredit perumahan ini kemudian disekuritisasi secara hibrid agar lebih menarik bagi investor yang terdiri dari bank, perusahaan sekuritas, reksadana, dana pensiun dan asuransi. Celakanya, 
banyak kredit tak terbayar dalam jumlah besar dan merata. Akibatnya, bank-bank kesulitan untuk membayar dan investor dengan cepat menarik dananya dari produk-produk perbankan disaat harga masih tinggi sehingga hal ini memacetkan perputaran uang di pasar hipotik. Hal ini menyebabkan pula struktur pasar uang yang produknya saling terkait satu sama lain menjadi terganggu. Termasuk juga jaminan obligasi utang (collaterlaised debt obligation/CDO) sebagai bentuk investasi kolektif dari sub-prime mortgage.

Lehman Brothers mengumumkan kerugian bertahap sebelum akhirnya bangkrut. Pada 16 Juni 2008, perusahan itu mengumumkan kerugian senilai 2,8 miliar dolar AS untuk paruh ke-dua 2008. Dilanjutkan dengan kerugian sebesar 3,9 miliar dolar AS pada paruh ke-tiga 2008 (10 September) dan berujung pada pengumuman kepailitannya pada 15 September 2008. Keguncangan serupa juga dialami secara hampir bersamaan oleh Merryl Linch, Citigroup, AIG dan berbagai lembaga keuangan besar lain.

\section{Permasalahan - permasalahan Pertumbuhan Ekonomi Yang di Hadapi}

Indonesia termasuk salah satu negara berkembang. Seperti juga negara berkembang lainnya, Indonesia menghadapi masalah ekonomi yang sama. Kemiskinan terjadi di manamana, jumlah pengangguran meningkat, tingkat kecerdasan masyarakat masih rendah, dan distribusi pendapatan tidak merata.

Di kota besar seperti Jakarta, keadaan seperti ini sudah menjadi pemandangan umum. Banyak orang yang hidup kurang beruntung terpaksa hidup sebagai pemulung sampah. Oleh karena pendapatan yang diperoleh sangat rendah, anaknya tidak dapat disekolahkan sehingga tingkat kecerdasan anak tersebut tidak berkembang.

Hal ini juga menimbulkan kesenjangan ekonomi yang tajam antara orang yang berpenghasilan tinggi dan orang yang berpenghasilan rendah.

\section{a. Masalah Ekonomi di Negara Berkembang : Kemiskinan}

Kemiskinan merupakan perwujudan keadaan serta kekurangan. Setiap negara memilik ukuran batas kemiskinan yang berbeda dengan negara lain. Pemerintah Indonesia memberikan perhatian serius dalam menanggulangi masalah kemiskinan yang dialami masyarakat. Dari tahun ke tahun pemerintah terus berupaya menurunkan jumlah dan persentase penduduk miskin dengan berbagai cara, antara lain subsidi silang. Subsidi silang yang dilakukan pemerintah yaitu dengan menetapkan harga BBM untuk minyak tanah lebih rendah daripada bensin. Subsidi untuk bensin sedikit demi sedikit dikurangi dan nantinya dihilangkan sama sekali. Subsidi untuk minyak tanah masih dipertahankan agar masyarakat berpenghasilan rendah mampu membeli minyak tanah.

b. Masalah Ekonomi di Negara Berkembang : Keterbelakangan

Masalah keterbelakangan sangat berhubungan dengan masalah kualitas sumber daya manusia. Disamping itu, masalah keterlebakangan sangat erat hubungannya dengan rendahnya tingkat kemajuan dan pelayanan kesehatan, kurang terpeliharanya fasilatasfasilitas umum, dan rendahnya disiplin masyarakat.

Untuk mengatasi masalah-masalah tersebut, pemerintahan Indonesia berupaya meningkatkan kualitas sumber daya manusia, misalnya dengan meningkatkan mutu pendidikan nasional. Persentase alokasi dana untuk pendidikan pada anggaran APBN setiap tahunnya ditingkatkan. Hal ini dimaksudkan untuk membantu sekolah yang kekurangan sarana dan prasarana belajar, seperti gedung sekolah yang rusak, buku-buku pelajaran yang kurang dan murid-murid yang memerlukan bantuan biaya sekolah.

c. Masalah Ekonomi di Negara Berkembang : Pengangguran

Masalah lain yang dihadapi negara berkembang dalam pembangunan ekonomi adalah masalah keterbatasan lapangan pekerjaan. Masalah pengangguran timbul karena ada ketimpangan antara jumlah angkatan kerja dan jumlah lapangan pekerjaan yang tersedia. 
Hal ini biasa terjadi karena negara yang bersangkutan sedang mengalami masa transisi perubahan struktur ekonomi dari negara agraris menjadi negara industry.

Negara berkembang memiliki pertumbuhan penduduk lebih cepat daripada pertumbuhan kesempatan kerja. Untuk mengatasi masalah pengangguran, pemerintahan melakukan pelatihan kerja sehingga tenaga kerja memiliki keahlian sesuai dengan lapangan kerja yang tersedia. Pelatihan kerja biasanya diselenggarakan oleh balai latihan kerja (BLK). Melalui program ini diharapkan peserta pelatihan dapat mengembangkan bakat dan keahlian untuk bekerja atau bahkan membuka usaha sendiri.

d. Masalah Ekonomi di Negara Berkembang : Kekurangan Modal

Kekurangan modal adalah satu cirri setiap negara yang sedang mengalami proses pembangunan ekonomi. Kekurangan modal tidak hanya menghambat percepatan pembangunan, tetapi juga menyebabkan kesukaran negara tersebut keluar dari kemiskinan. Perkembangan zaman dan modernisasi perekonomian memerlukan modal yang besar. Negara berkembang mengalami kesulitan yang sama, yaitu kekurangan modal. Hal ini disebabkan tingkat tabungan dan tingkat pembentukan modal yang rendah.

Untuk mengatasi kekurangan modal, pemerintah menarik investor, baik dari dalam maupun luar negeri. Misalnya BUMN menawarkan saham kepada investor agar bersedia bekerjasama. Dengan meningkatkan investasi, diharapkan tabungan permintahan juga meningkat. Jika tabungan pemerintah meningkat, modal yang dikumpulkan pun akan lebih banyak.

e. Masalah Ekonomi di Negara Berkembang : Ketidakmerataan hasil pembangunan

Masalah lain yang dihadapi negara berkembang adalah melaksanakan pembangunan ekonomi adalah masalah pemerataan pendapatan. Contohnya di Indonesia, perekonomian terkonsentrasi di kota-kota besar, terutama di pulau jawa. Sementara itu, dilihat dari hak penguasaan sector industry, perekonomian didominasi oleh kurang lebih 200 konglomerat. Hal ini disebabkan sistem perekonomian yang terlau terpusat kepada negara sehingga potensi daerah kurang diperhatikan.

Melalui perubahan sistem perundang-undangan pemerintah Indonesia mulai memperbaiki sistem perekonomian negara. Sistem perundang-undangan yang memihak praktik monopoli mulai dihapus. Di samping itu, untuk mengurangi kesenjangan pembangunan antara pemerintah pusat dan daerah, diberlakukan undang-undang otonomi daerah. Daerah diberi kebebasan untuk mengembangkan potensi dan pemerintah pusat tidak lagi terlalu campur tangan dalam urusan rumah tangga pemerintah daerah

Secara ringkas permasalah - permasalahan utama dari ekonomi makro dapat dikemukakan sebagai berikut :

a. Masalah pertumbuhan : ekonomipertumbuhan ekonomi berarti perkembangan dalam kegiatan perekonomian yang menyediakan barang dan jasa yang diproduksikan dalam masyarakat bertambah dan kemakmuran masyarakat meningkat.

b. Masalah ketidakstabilan kegiatan ekonomi : perekonomian suatu negara tidak selalu berkembang secara teratur atau dengan kata lain kegiatan perekonomian mengalami naik turun. Adakalanya perekonomian berkembang sangat pesat sehingga menimbulkan kenaikan harga-harga. Pada periode yang lainnya perekonomian mengalami kemunduran dan adakalanya mengalami kemerosotan dan berada pada titik terendah. Pergerakan naik turun kegiatan perekonomian suatu negara yang menyebabkan tidak stabilnya kegiatan ekonomi dalam jangka panjang dinamakan konjungtur.

c. Masalah pengangguran dan inflasi : Pengangguran adalah suatu keadaan dimana seseorang yang tergolong dalam angkatan kerja dan ingin mendapatkan pekerjaan tetapi belum memperoleh pekerjaan. Di sisi lain kondisi ekonomi suatu negara mengalami 
kenaikan harga yang terus menerus, sehingga terjadi inflasi yang sangat merugikan masyarakat, terutama masyarakat golongan ekonomi lemah.

d. Masalah neraca perdagangan dan neraca pembayaran : perekonomian terbuka berarti sesuatu perekonomian yang mempunyai hubungan ekonomi dengan negara lain, dan terutama dilakukan dengan menjalankan kegiatan ekspor dan impor, yang nantinya akan menentukan besarnya neraca perdagangan. Neraca pembayaran adalah suatu ringkasan pembukuan yang menunjukkan aliran pembayaran yang dilakukan negara lain ke dalam negeri, dan dari dalam negeri ke negara lain.

\section{Kemiskinan di Negara Berkembang}

Upaya memerangi kemiskinan bisa terhambat jika negara-negara berkembang dipaksa untuk memotong investasi produktif dan sumber daya manusia. Sehingga menyebabkan bantuan pembangunan yang rendah dan pajak penghasilan yang berkurang.

Bank Dunia juga menyatakan adanya potensi peningkatan masyarakat sangat miskin di negara berkembang sebesar 26 juta pada 2020 karena terhambatnya bantuan. Selain itu jika bantuan bilateral untuk pembangunan menurun, seperti yang pernah terjadi sebelumnya, dapat mempengaruhi rata-rata pertumbuhan ekonomi jangka panjang negara berkembang dan berpotensi meningkatkan masyarakat sangat miskin sampai 26 juta jiwa pada 2020. Sebab Bank Dunia menilai di negara berkembang saat ini terjadi kesenjangan pembiayaan pembangunan. Kesenjangan pembiayaan di negara berembang secara keseluruhan diperkirakan mencapai 210 miliar dollar AS pada 2010 dan menurun menjadi 180 miliar dollar AS pada 2011. Bank Dunia memperkirakan laju modal dari sektor swasta untuk negara berkembang pada 2009 mencapai 454 miliar dollar AS, dan 2012 diperkirakan meningkat tipis 771 miliar dollar AS atau 3,2 peren dari produk domestik bruto (PDB). Sedangkan pertumbuhan di negara berkembang, Bank Dunia memperkirakan sekitar enam persen setiap tahun pada 2010,2011 dan 2012 naik dari 2009 sebesar 1,7 persen. Hal ini didasarkan pada antisipasi perlambatan pertumbuhan di China sebagai negara yang memiliki pertumbuhan ekonomi terbesar pada dua tahun mendatang dari 9,5 pada 2010 menjadi 8,5 persen pada 2011.

\section{Faktor - faktor Penyebab Kemiskinan Yang Berkembang}

Kemiskinan identik dengan negara berkembang, dari sisi individu bahwa penyebab dari faktor kemiskinan dan pengangguran adalah kemalasan untuk mencarinya, kemiskinan merupakan sebuah masalah yang sudah umum, di setiap negara merupakan masalah dalam mengetas kemiskinan, ada beberapa faktor individu yang menyebabkan kemiskinan, mulai dari masalah individu sampai masalah struktural ;

a. Di lihat dari Faktor Individu =>Penyebab individual yakni kemiskinan akibat dari perilaku atau kemampuan dari orang tersebut, misalnya : malas, atau menunggu yang sifat nya spekulasi.

b. Di lihat dari Faktor Keluarga $=>$ Faktor keluarga bukanlah faktor individu yang di keluarkan/ di lontarkan oleh sekelompok orang yang mengatakankemiskinan tidak akan timbul jika ada kemauan yang kuat dari diri sendiri. Faktor ini menghubungkan kemiskinan karena keadaan dan pendidikan keluarga.

c. Di lihat dari Faktor Subkultural =>Penyebab sub-kebudayaan atau kebiasaan yang menghubungkan faktor kemiskinan di sebabkan oleh kehidupan sehari-hari yang di pelajari ataudi jalankan dalam lingkungan.

d. Di lihat dari Faktor Agensi =>Penyebab agensi sosial melihat kemiskinan di sebabkan dari orang lain, termasuk perang, Pemrintah, dan ekonomi. 
e. Di lihat dari Faktor Struktur $\Rightarrow$ Penyebab struktural sering menimbulkan pertanyaan, faktor ini erat kaitannya dengan struktur sosial baik dalam masyarakat maupun dalam sosial.

\section{Konsep - Konsep Tentang Kemiskinan}

Kemiskinan merupakan permasalahan kemanusiaan purba. Ia bersifat laten dan aktual sekaligus. Ia telah ada sejak peradaban manusia ada dan hingga kini masih menjadi masalah sentral di belahan bumi manapun.

Kemisikinan merupakan faktor dominan yang mempengaruhi persoalan kemanusiaan lainnya, seperti keterbelakangan, kebodohan, ketelantaran, kematian dini. Problema buta hurup, putus sekolah, anak jalanan, pekerja anak, perdagangan manusia (human trafficking) tidak bisa dipisahkan dari masalah kemiskinan.

Berbagai upaya telah dilakukan, beragam kebijakan dan program telah disebarterapkan, berjumlah dana telah dikeluarkan demi menanggulangi kemiskinan.

a. Menurut John Friedman

Kemiskinan adalah ketidaksamaan kesempatan untuk mengakumulasikan basis kekuasaan sosial, meliputi modal yang produktif, sumber keuangan, organisasi sosial dan politik (Kemiskinan tidak hanya berkaitan dengan aspek sosial saja, tapi juga aspek natural material).

b. Menurut Wolf Scott

Kemiskinan pada umumnya didefinisikan dari segi pendapatan (Dalam jumlah uang) ditambah dengan keuntungan non-material yang diterima seseorang, cukup tidaknya memiliki aset seperti tanah, rumah, uang,emas dan lain-lain dimana kemiskinan nonmaterial yang meliputi kekebebasan hak untuk memperoleh pekerjaan yang layak.

c. Menurut Bank Dunia

Bahwa aspek kemiskinan yaitu pendapatan yang rendah, kekurangan gizi atau keadaan kesehatan yang buruk serta pendidikan yang rendah.

\section{Kondisi Pertumbuhan di Indonesia dan Cara Mengatasi Permasalahannya}

a. Jumlah penduduk Indonesia

Besarnya sumber daya manusia Indonesia dapat di lihat dari jumlah penduduk yang ada. Jumlah penduduk di Indonesia berada pada urutan keempat terbesar setelah Cina, India, dan Amerika Serikat.

b. Pertumbuhan Penduduk Indonesia

Peningkatan penduduk dinamakan pertumbuhan penduduk. Angka pertumbuhan penduduk Indonesia Lebih kecil dibandingkan Laos, Brunei, dan Filipina.

c. Kepadatan penduduk Indonesia

Kepadatan penduduk merupakan perbandingan jumlah penduduk terhadap luas wilayah yang dihuni. Ukuran yang digunakan biasanya adalah jumlsh penduduk setiap satu $\mathrm{km}^{2}$ atau setiap $1 \mathrm{mil}^{2}$. permasalahan dalam kepadatan penduduk adalah persebarannya yang tidak merata. Kondisi demikian menimbulkan banyak permasalahan, misalnya pengangguran, kemiskinan, kriminalitas, pemukiman kumuh dsb.

d. Susunan penduduk Indonesia

Sejak sensesus penduduk tahun 1961, piramida penduduk Indonesia berbentuk limas atau ekspansif. Artinya pada periode tersebut, jumlah penduduk usia muda lebih banyak daripada penduduk usia tua. Susunan penduduk yang seperti itu memberikan konsekuensi terhadap hal-hal berikut.

- Penyediaan fasilitas kesehatan.

- Penyediaan fasilitas pendidikan bagi anak usia sekolah 
- Penyediaan lapangan pekerjaan bagi penduduk kerja

- Penyediaan fasilitas social lainnya yang mendukung perkembangan penduduk usia muda.

\section{Kondisi Kemiskinan di Indonesia dan Cara Mengatasi Permasalahannya}

a. Masalah kemiskinan di Indonesia sarat sekali hubungannya dengan rendahnya tingkat Sumber Daya Manusia (SDM). dibuktikan oleh rendahnya mutu kehidupan masyarakat Indonesia meskipun kaya akan Sumber Daya Alam (SDA). Sebagaimana yang ditunjukkan oleh rendahnya Indeks Pembangunan Masyarakat (IPM) Indonesia pada tahun 2002 sebesar 0,692. yang masih menempati peringkat lebih rendah dari Malaysia dan Thailand di antara negara-negara ASEAN. Sementara, Indeks Kemiskinan Manusia (IKM) Indonesia pada tahun yang sama sebesar 0,178. masih lebih tinggi dari Filipina dan Thailand. Selain itu, kesenjangan gender di Indonesia masih relatif lebih besar dibanding negara ASEAN lainnya.keren.web.id

b. Tantangan selanjutnya adalah otonomi daerah. di mana hal ini mempunyai peran yang sangat signifikan untuk mengentaskan atau menjerumuskan masyarakat dari kemiskinan. Sebab ketika meningkatnya peran keikutsertaan pemerintah daerah dalam penanggulangan kemiskinan. maka tidak mustahil dalam jangka waktu yang relatif singkat kita akan bisa mengentaskan masyarakat dari kemiskinan pada skala nasional terutama dalam mendekatkan pelayanan dasar bagi masyarakat. Akan tetapi ketika pemerintah daerah kurang peka terhadap keadaan lingkungan sekitar, hal ini sangat berpotensi sekali untuk membawa masyarakat ke jurang kemiskinan, serta bisa menimbulkan bahaya laten dalam skala Nasional

\section{Kebijakan dan Program Penuntasan Kemiskinan}

Upaya penanggulangan kemiskinan Indonesia telah dilakukan dan menempatkan penanggulangan kemiskinan sebagai prioritas utama kebijakan pembangunan nasional. Kebijakan kemiskinan merupakan prioritas Rencana Pembangunan Jangka Menengah (RPJM) 2004-2009 dan dijabarkan lebih rinci dalam Rencana Kerja Pemerintah (RKP) setiap tahun serta digunakan sebagai acuan bagi kementrian, lembaga dan pemerintah daerah dalam pelaksanaan pembangunan tahunan.

Adapun langkah jangka pendek yang diprioritaskan antara lain sebagai berikut:

a. Mengurangi kesenjangan antar daerah dengan;

- Penyediaan sarana-sarana irigasi, air bersih dan sanitasi dasar terutama daerahdaerah langka sumber air bersih

- Pembangunan jalan, jembatan, dan dermaga daerah-daerah tertinggal..

- Redistribusi sumber dana kepada daerah-daerah yang memiliki pendapatan rendah dengan instrumen Dana Alokasi Khusus (DAK) .

b. Perluasan kesempatan kerja dan berusaha dilakukan melalui bantuan dana stimulan untuk modal usaha, pelatihan keterampilan kerja dan meningkatkan investasi dan revitalisasi industri.

c. Khusus untuk pemenuhan sarana hak dasar penduduk miskin diberikan pelayanan antara lain

- Pendidikan gratis sebagai penuntasan program belajar 9 tahun termasuk tunjangan bagi murid yang kurang mampu;

- Jaminan pemeliharaan kesehatan gratis bagi penduduk miskin di puskesmas dan rumah sakit kelas tiga.

\section{Kesimpulan}


Diambil kesimpulan bahwa Masalah Pertumbuhan, Kemiskinan dan Distribusi Pendapat bisa terjadi di Negara maju maupun Negara sedang berkembang. Selain itu juga manjadi masalah dunia sejak berabad-abad lalu. hingga kini masih menjadi bagian dari persoalan terberat dan paling krusial di dunia ini. Seiring berkembangnya pemikiran bahwa, maka upaya untuk mengatasi Masalah Pertumbuhan, Kemiskinan dan Distribusi Pendapat pun kini dikaitkan dengan perbaikan sistem dan struktur, tidak semata-mata bertumpu pada aksi sesaat berupa crash program. Namun kini pemerintahan Indonesia sedikit demi sedikit telah memperbaiki keadaan ekonomi rakyat dengan mengatasi Masalah Pertumbuhan, Kemiskinan dan Distribusi Pendapat yang terjadi di Indonesia. Sekarang ini pemerintahan Indonesia telah melakukan program Bantuan Langsung Tunai bagi masyarakat menengah kebawah. Kebijakan pemberantasan Masalah Pertumbuhan, Kemiskinan dan Distribusi Pendapat harus menyentuh akar masalah. Untuk itu, kebijakan strategis yang harus ditempuh adalah perluasan dan pemerataan pendidikan, peningkatan layanan kesehatan, pembangunan perumahan, penciptaan lapangan kerja, pembangunan infrastruktur untuk memperlancar transaksi ekonomi dan perdagangan, serta pembangunan daerah untuk mengurangi disparitas ekonomi antar wilayah

\section{Saran}

Pemerintah Indonesia harus jeli melihat masyarakat mana yang benar-benar membutuhkan bantuan. Selain itu pemerintah Indonesia juga hgarus memberantas kemiskinan untuk menyejahterakan rakyatnya menjadi rakyat yang makmur dan sejahtera dan juga segala kebuthanya tercukupi.

\section{Daftar Pustaka}

http://news.detik.com/read/2010/01/13/083906/1277194/10/krisis-ekonomi-global-dankondisi-perekonomian-domestik

http://satpolppjambi.blogspot.com/2012/03/masalah-ekonomi-di-negara-berkembang.html

http://id.shvoong.com/social-sciences/economics/2173859-masalah-yang-dihadapipemerintah-dalam/\#ixzz1p6hIoSdj

http://eone87.wordpress.com/2010/04/02/konsep-kemiskinan-dan-strategipenanggulangannya/

http://www.anneahira.com/faktor-penyebab-kemiskinan.htm

Aaldoankz.wordpress.com/2011/03/18/kemiskinan-dan-kesenjangan-pendapatan/

http://wartawarga.gunadarma.ac.id/2011/04/kebijakan-pemerintah-dalam-menanggulangikemiskinan-di-indonesia/ 